\title{
An Evaluation of Aquifer Intercommunication Between the Unconfined and Rattlesnake Ridge Aquifers on the Hanford Site
}

\author{
E. J. Jensen
}

October 1987

Prepared for the U.S. Department of Energy under Contract DE-AC06-76RLO 1830

Pacific Northwest Laboratory

Operated for the U.S. Department of Energy by Battelle Memorial Institute 


\title{
DISCLAIMER
}

This report was prepared as an account of work sponsored by an agency of the United States Government. Neither the United States Government nor any agency thereof, nor Battelle Memorial Institute, nor any of their employees, makes any warranty, expressed or implied, or assumes any legal liability or responsibility for the accuracy, completeness, or usefulness of any information, apparatus, product, or process disclosed, or represents that its use would not infringe privately owned rights. Reference herein to any specific commercial product, process, or service by trade name, trademark, manufacturer, or otherwise, does not necessarily constitute or imply its endorsement, recommendation, or favoring by the United States Government of any agency thereof, or Battelle Memorial Institute. The views and opinions of authors expressed herein do not necessarly state or reflect those of the United States Government or any agency thereof, or Battelle Memorial Institute.

\author{
PACIFIC NORTHWEST LABORATORY \\ operated by \\ BATTELLE MEMORIAL INSTITUTE \\ for the \\ UNITED STATES DEPARTMENT OF ENERGY \\ under Contract DE-AC06-76RLO 1830
}

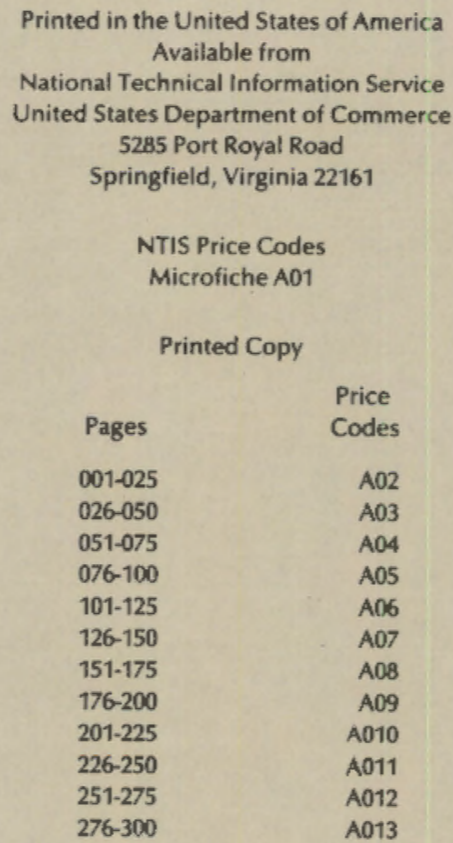




\section{1}

AN EVALUATION OF AQUIFER INTERCOMMUNICATION BETWEEN THE UNCONFINED AND RATTLESNAKE RIDGE AQUIFERS ON THE HANFORD SITE

E. J. Jensen

October 1987

Prepared for the U.S. Department of Energy under Contract DE-AC06-76RLO 1830

Pacific Northwest Laboratory Richland, Washington 99352 



\section{EXECUTIVE SUMMARY}

During 1986, Pacific Northwest Laboratory conducted a study of a portion of the Rattiesnake Ridge aquifer (confined aquifer) that lies beneath the B Pond - Gable Mountain Pond area of the Hanford Site. The purpose of this study was to determine the extent of intercommunication between the unconfined aquifer and the uppermost regionally extensive confined aquifer, referred to as the Rattlesnake Ridge aquifer.

Hydraulic head data and chemical data were collected from the ground water in the study area during December 1986. The hydraulic head data were used to determine the effects caused by water discharged to the ground from $B$ Pond on both the water table of the unconfined aquifer and the potentiometric surface of the confined aquifer. The chemical data were collected to determine the extent of chemical constituents migrating from the unconfined aquifer to the confined aquifer.

Analysis of chemical constituents in the Rattlesnake Ridge aquifer demonstrated that communication between the unconfined and confined aquifers had occurred. However, the levels of contaminants found in the Rattlesnake Ridge aquifer during this study were below the DOE Derived Concentration Guides (PNL 1987). 



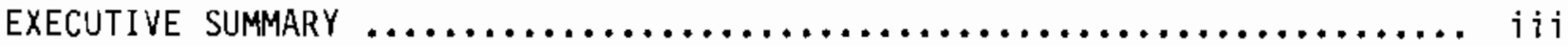

INTROOUCTION $\ldots \ldots \ldots \ldots \ldots \ldots \ldots \ldots \ldots \ldots \ldots \ldots \ldots \ldots \ldots \ldots \ldots \ldots \ldots \ldots \ldots \ldots$

GEOLOGIC CHARACTERISTICS OF THE UNCONFINED AND CONFINED AQUIFERS ....... 3

HYDRAULIC HEAD MEASUREMENTS $\ldots \ldots \ldots \ldots \ldots \ldots \ldots \ldots \ldots \ldots \ldots \ldots \ldots \ldots \ldots \ldots \ldots \ldots$

CHEMICAL ANALYSIS $\ldots \ldots \ldots \ldots \ldots \ldots \ldots \ldots \ldots \ldots \ldots \ldots \ldots \ldots \ldots \ldots \ldots \ldots \ldots$

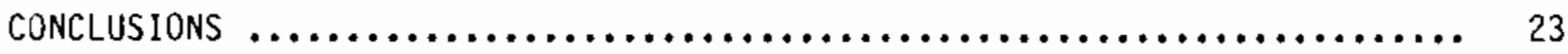

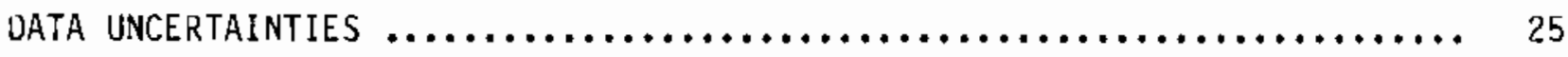

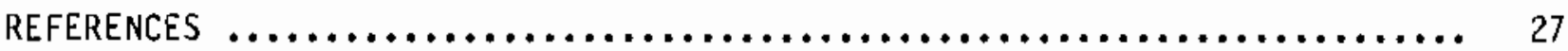

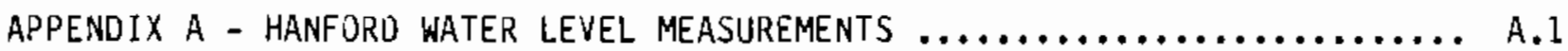




\section{FIGURES}

1 Map of Hanford Site Showing the Study Area $\ldots \ldots \ldots \ldots \ldots \ldots \ldots \ldots$............

2 Potentiometric Surface Map of the Rattlesnake Ridge Confined Aquifer Within the Hanford Site, December 1986 ................ 5

3 Water Table Map of the B Pond - Gable Mountain Pond Area at the Hanford Site, December 1986 ....................... 8

4 Changes in the Water Table Elevations from December 1985 to December 1986

5 Changes in the Potentiometric Elevations from December 1985 to December 1986 in the Rattlesnake Ridge Aquifer ............... 10

6 Construction Diagrams and Geology of Wells 699-42-40A, $699-42-40 \mathrm{~B}$, and $699-42-40 \mathrm{C}$

7 Hydrograph of Wells 699-42-40A, 699-42-40B, and 699-42-40C ....... 12

8 Unconfined Aquifer, Average Tritium Concentrations for August, September, October, and November 1986

\section{TABLES}

1 Wells Used to Sample the Rattlesnake Ridge Aquifer ............. 15

2 Tritium Concentrations in the Rattlesnake Ridge Aquifer ......... 16

3 Nitrate Concentrations in the Rattlesnake Ridge Aquifer .......... 17

4 Cobalt-60 Concentrations in the Rattlesnake Ridge Aquifer ........ 18

5 Cesium-137 Concentrations in the Rattlesnake Ridge Aquifer ........ 19

6 Ruthenium-106 Concentrations in the Rattlesnake Ridge Aquifer ...... 20

7 Tritium Concentrations in Well $699-42-40 c \ldots \ldots \ldots \ldots \ldots \ldots \ldots . \ldots . \ldots 21$

A.1 Hanford Water Level Measurements in Unconfined Aquifer, December 1986

A.2 Hanford Water Level Measurements in the Rattlesnake Ridge Aquifer, December 1986 


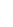




\section{INTRODUCTION}

The purpose of this task of the Hanford Ground-Water Monitoring Project (funded by the U.S. Department of Energy) was to monitor the uppermost regionally extensive confined aquifer in the Columbia River Basalt Group, the Rattlesnake Ridge aquifer. This monitoring, done to determine the extent of aquifer intercommunication between the confined and unconfined aquifers resulting from activities of the 200-East and 200-West Areas, was accomplished through collection and analysis of hydraulic head and chemical data. Concentrations of radionuclides in the Rattlesnake Ridge aquifer were compared to the radionuclides in the unconfined aquifer and to concentrations reported by Graham, Last and Fecht (1984). Hydraulic head data were compared to measurements by Jensen, Schatz and Liikala (1985) to determine the extent of any fluctuations in water level elevations from those of December 1985.

The study took place on the Hanford Site, which is located in southcentral Washington State (see Figure 1). The study area was limited mainly to the B Pond - Gable Mountain Pond area. This area contains the only extensive well network completed in the Rattlesnake Ridge aquifer on the Hanford Site. 


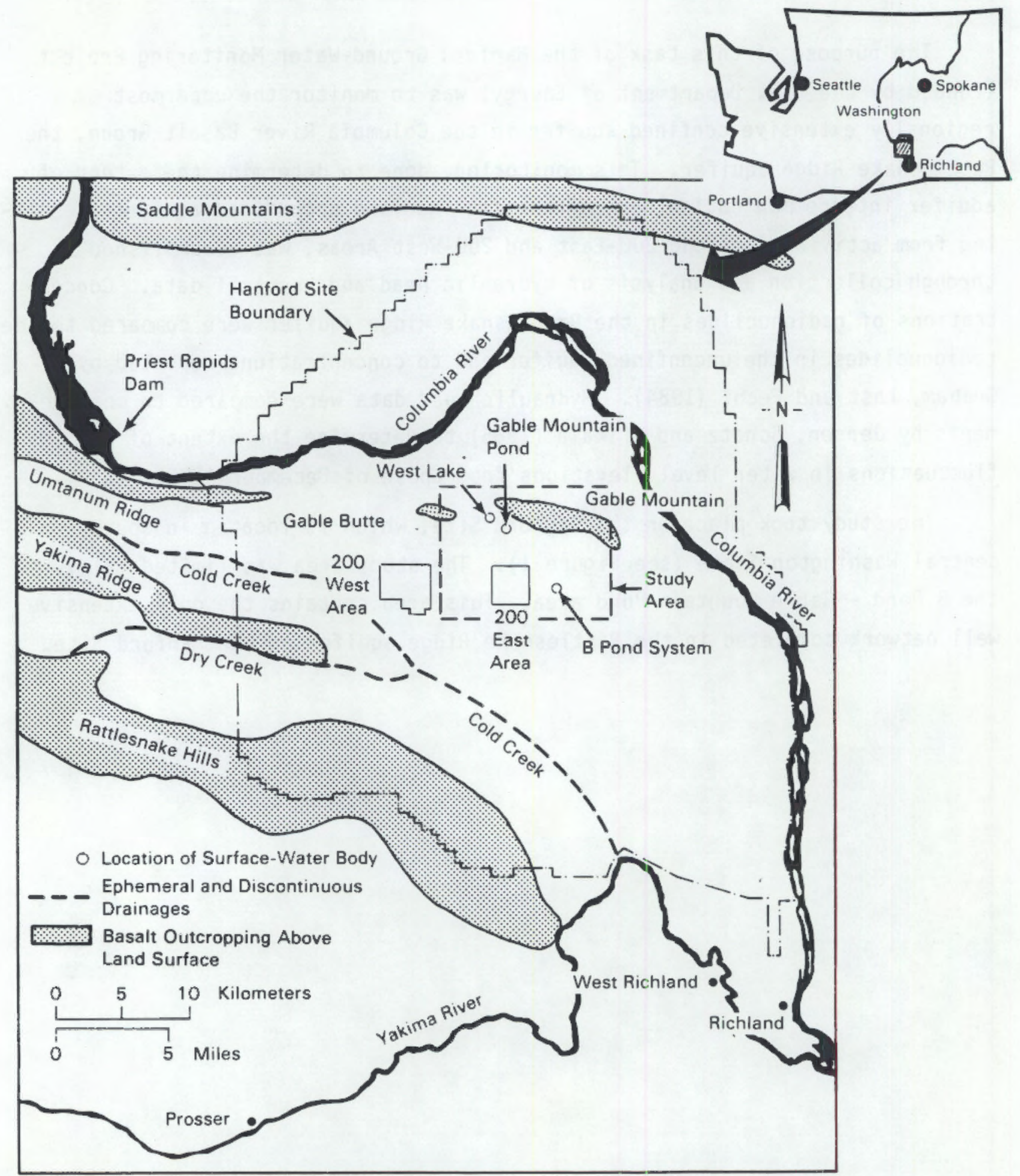

FIGURE 1. Map of Hanford Site Showing the Study Area 


\section{GEOLOGIC CHARACTERISTICS OF THE UNCONFINED AND CONFINED AQUIFERS}

The unconfined aquifer is contained in the geologic units of the glaciofluvial sediments (informally called the Hanford formation) and the semiconsolidated silts, sands, and gravels of the Ringold Formation. The bottom of the unconfined aquifer throughout most of the study area is the top of the Elephant Mountain Basalt. In some areas the basal Ringold forms the bottom of the aquifer. In places where the Elephant Mountain Basalt is absent, other basalt flows or interbeds form the bottom of the aquifer (as reported by Myers/Price et a1. 1979; Graham, Last and Fecht 1984; Fecht 1978; and others). The Rattlesnake Ridge aquifer occurs mainly within the Rattlesnake Ridge interbed. The top of the interbed is confined by the Elephant Mountain Basalt and the bottom is confined by the Pomona Basalt. Throughout this report the Rattlesnake Ridge aquifer will be referred to as the confined aquifer. A geologic description of each unit in the unconfined and confined aquifers follows (in descending order).

The Hanford formation consists of catastrophic flood sediments that were deposited when ice dams in western Montana and northern Idaho were breached and massive volumes of water spilled abruptly across what is now eastern and central Washington. Thick sequences of sediments were deposited across the Hanford Site by several episodes of Pleistocene flooding (Tallman et al. 1979).

In the central portion of the Hanford Site, the Ringold Formation has been divided into four units: 1) sand and gravel of the basal Ringold member; 2) clay, silt, and fine sand with minor gravel lenses of the lower Ringold member; 3) occasionally cemented sand and gravel of the middle Ringold member; and 4) silt and fine sand of the upper Ringold member (Brown 1959). These units pinch out laterally to the north and east, where the Ringold sediments consist of slackwater and over-bank deposits.

The Elephant Mountain Member of the Saddle Mountains Basalt consists of two basalt flows within the Pasco Basin (Elephant Mountain 1 and Elephant Mountain 2). A zone of sands and clays between these two basalt flows is referred to as the Elephant Mountain aquifer. The ground-water flow in this 
aquifer is believed to parallel that of the Rattlesnake Ridge aquifer, because the hydraulic head values of the two aquifers are approximately equal (Graham, Last and Fecht 1984).

The El ephant Mountain aquifer is in contact with the unconfined aquifer in the northeast corner of 200-East Area, where the Elephant Mountain 1 basalt flow is absent. Graham, Last and Fecht (1984) identified several areas where both of the Elephant Mountain flows are completely eroded (dotted areas in Figure 2). The Rattlesnake Ridge aquifer is exposed to the unconfined aquifer in these areas of erosion. The Elephant Mountain aquifer probably discharges to the unconfined aquifer, although it may be influenced locally by the groundwater mound under B Pond (Graham, Last and Fecht 1984).

The Rattlesnake Ridge interbed can be locally divided into four units. These are, in descending order: 1) a tuffite derived from reworking the volcanic ash unit, 2) a volcanic ash unit, 3) a fluvial-flood plain unit, and 4) a clay matrix-supported basaltic conglomerate formed by weathering and reworking of the Pomona flow top. (a) The lithologies of the Rattlesnake Ridge interbed control the movement of ground water within the confined aquifer. Its thickness ranges from 50 to $70 \mathrm{ft}$, and hydraulic conductivity ranges from 10 to $10^{2} \mathrm{~m} /$ day (DOE 1982).

The Pomona Member of the Saddle Mountains Basalt consists of several dense basalt flows that are up to $200 \mathrm{ft}$ thick in some locations. The fine-grained to glassy texture of the Pomona is characteristic throughout the study area (Myers and Price 1981).

The confined aquifer is recharged in the surrounding higher elevations by irrigation and rain (Graham, Last and Fecht 1984). Erosion of the Elephant Mountain Basalt and the Rattlesnake Ridge interbed in the vicinity of West Lake has allowed the Rattlesnake Ridge aquifer to discharge to the unconfined aquifer. The confined waters discharge to the unconfined aquifer where they eventually discharge to the Columbia River (Fecht 1978; Graham, Last and Fecht 1984).

(a) 1984 data from G. V. Last and K. R. Fecht of Rockwell Hanford Operations, Richland, Washington, as a result of their research of the ground-water geology of the intercommunication study area on the Hanford Site. 


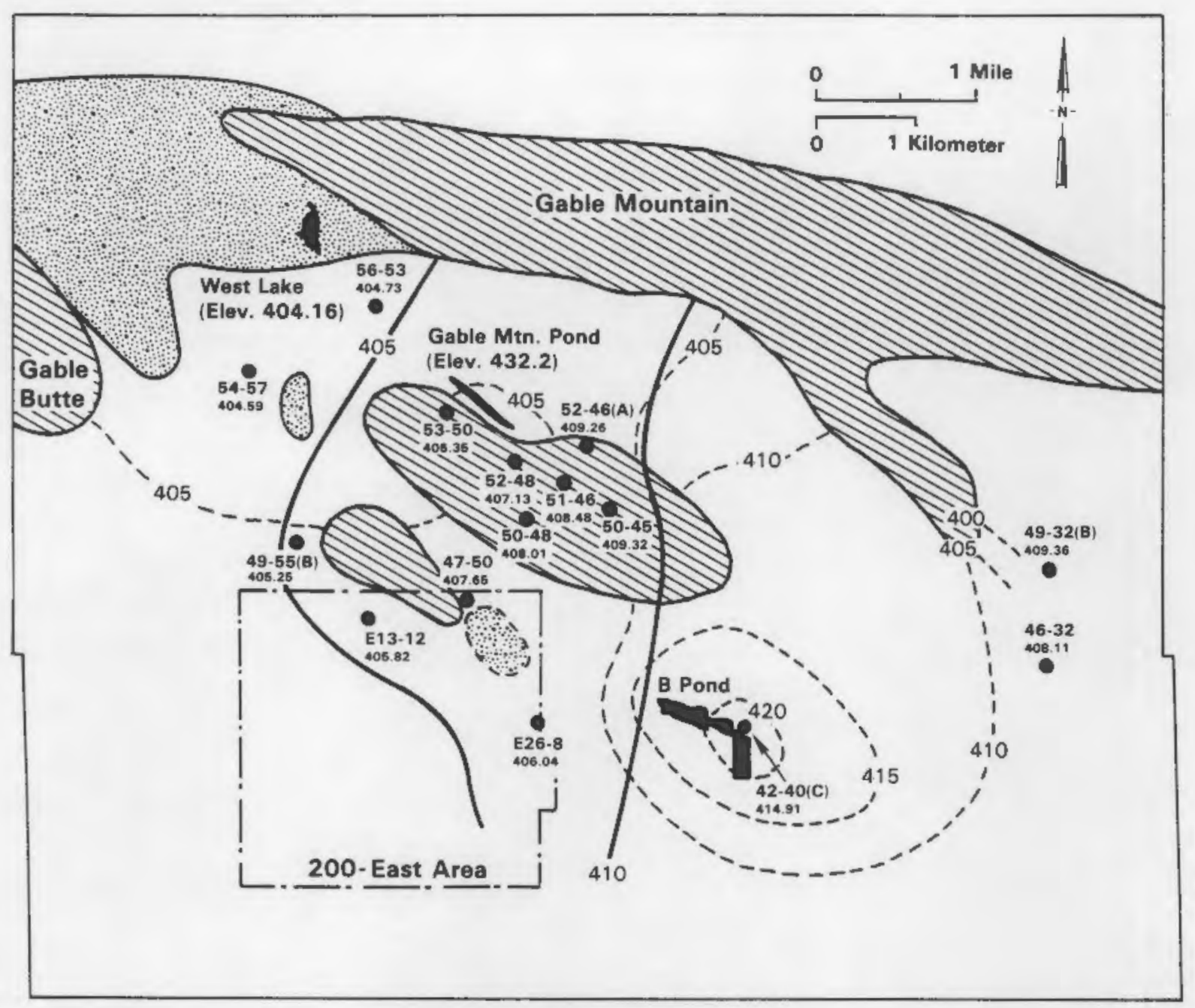

Contours of the Confined Aquifer in Increments of $\mathbf{5} \mathrm{ft}$ Above Mean Sea Level Contours of the Unconfined Aquifer in - - Increments of $5 \mathrm{ft}$ Above Mean Sea Level

- Wells Used in Preparation of Map

Ponds (Water surface elevation in feet above mean sea level)

IIJ Estimated Besalt Outcrops Above Water Table (Graham, Last and Fecht 1984)

Areas of Complete Erosion of the Elephant Mountain Basait (Graham, Last and Fecht 1984)

\section{$\frac{T .13 \mathrm{~N}}{T .12 \mathrm{~N}}$}

FIGURE 2. Potentiometric Surface Map of the Rattlesnake Ridge Confined Aquifer Within the Hanford Site, December 1986 



\section{HYDRAULIC HEAD MEASUREMENTS}

Water levels were measured in the unconfined and Rattlesnake Ridge aquifers during December 1986 (see Appendix Tables A.1 and A.2) to determine the effects of water discharging to the ground from the 200-East and 200-West Areas in the B Pond - Gable Mountain Pond area. Figures 2 through 5 were drawn from these data and from data in Jensen, Schatz, and Liikala (1985).

The water table surface in the unconfined aquifer is illustrated in Figure 3, and the contours of the potentiometric surface of the Rattlesnake Ridge aquifer are compared with the water table surface of the unconfined aquifer in Figure 2.

Elevations in the unconfined aquifer from December 1985 to December 1986 are compared in Figure 4. In this figure, a minus sign means that the water table elevation has dropped since December 1985, and a plus sign means that it has risen. The elevation of the water table in the unconfined aquifer has decreased slightly in the southeast corner of the 200-East Area, around B Pond, and near Gable Mountain Pond during the past year (identified by minus signs in Figure 4). A slight increase was observed over the rest of the $B$ Pond - Gable Mountain Pond area (identified by plus signs in Figure 4).

Changes in the potentiometric surface of the Rattlesnake Ridge aquifer from December 1985 to December 1986 are illustrated in Figure 5. A decrease in elevation of the potentiometric surface of the Rattlesnake Ridge aquifer has occurred around B Pond since December 1985. Water levels in wells 699-42-40C and 299-E26-8, completed in the confined aquifer, decreased by 0.41 and $0.38 \mathrm{ft}$, respectively. Well $699-42-40 \mathrm{C}$ is located downgradient of $B$ Pond, and well 299-E26-8 is located on the east side of the 200-East Area, the same area where the largest decrease in water levels occurred in the unconfined aquifer (Figures 4 and 5). The potentiometric surface of the Rattlesnake Ridge aquifer rose in all other wells measured within the study area.

Wells $699-42-40 A$ and $699-42-40 B$ are completed in the unconfined aquifer, and well 699-42-40C is completed in the Rattlesnake Ridge aquifer (Figure 6). These wells are adjacent to each other and near $B$ Pond. The hydrographs of wells $699-42-40 A, B, C$ (Figure 7) illustrate the relationship between the 


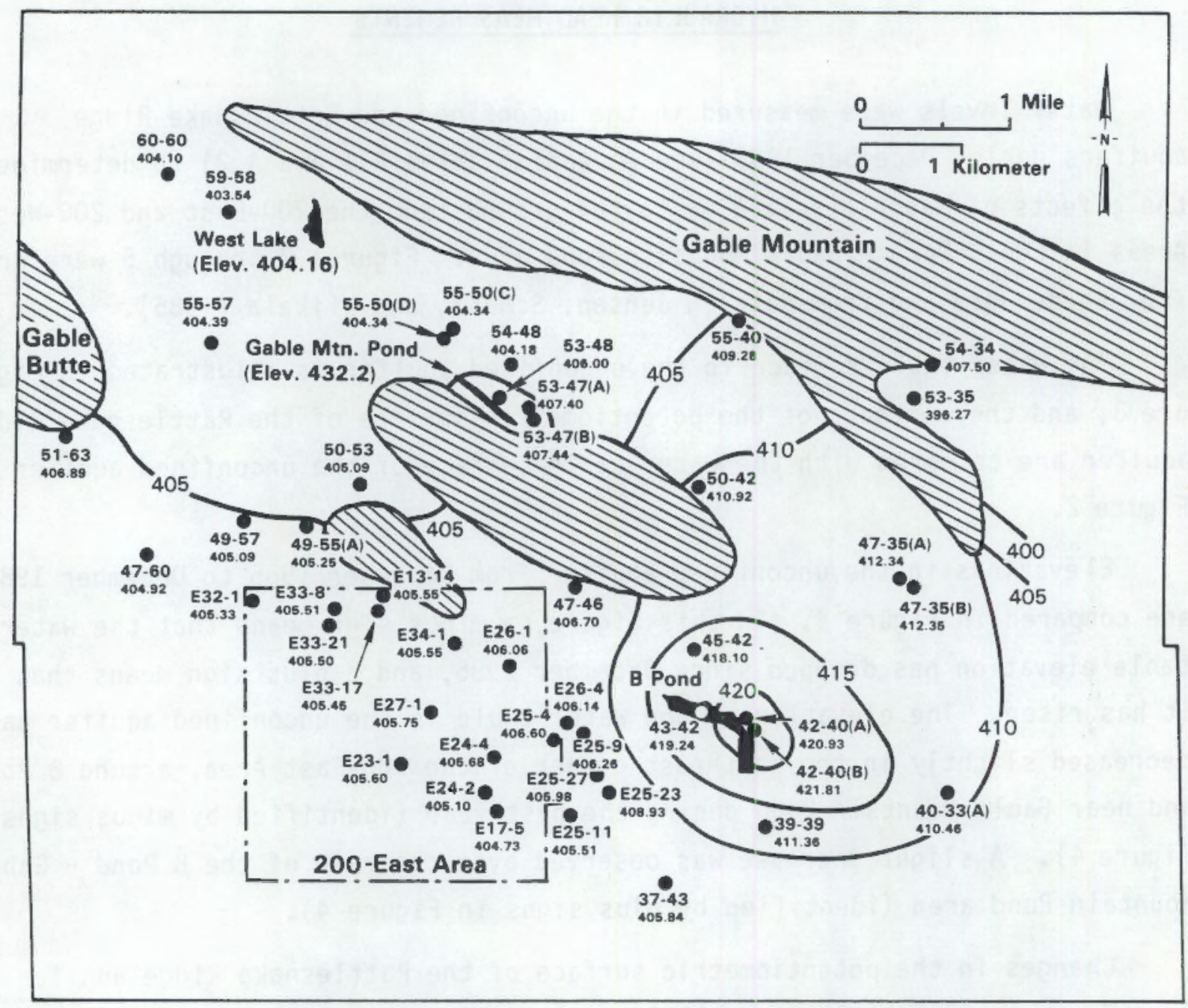

Contours of the Unconfined Aquifer in

Wells Used in Preparation of Map
Ponds, Water Surface Elevation
(ft-MSL)

$\frac{T .13 \mathrm{~N}}{\mathrm{~T} .12 \mathrm{~N}}$

FIGURE 3. Water Table Map of the B Pond - Gable Mountain Pond Area at the Hanford Site, December 1986 


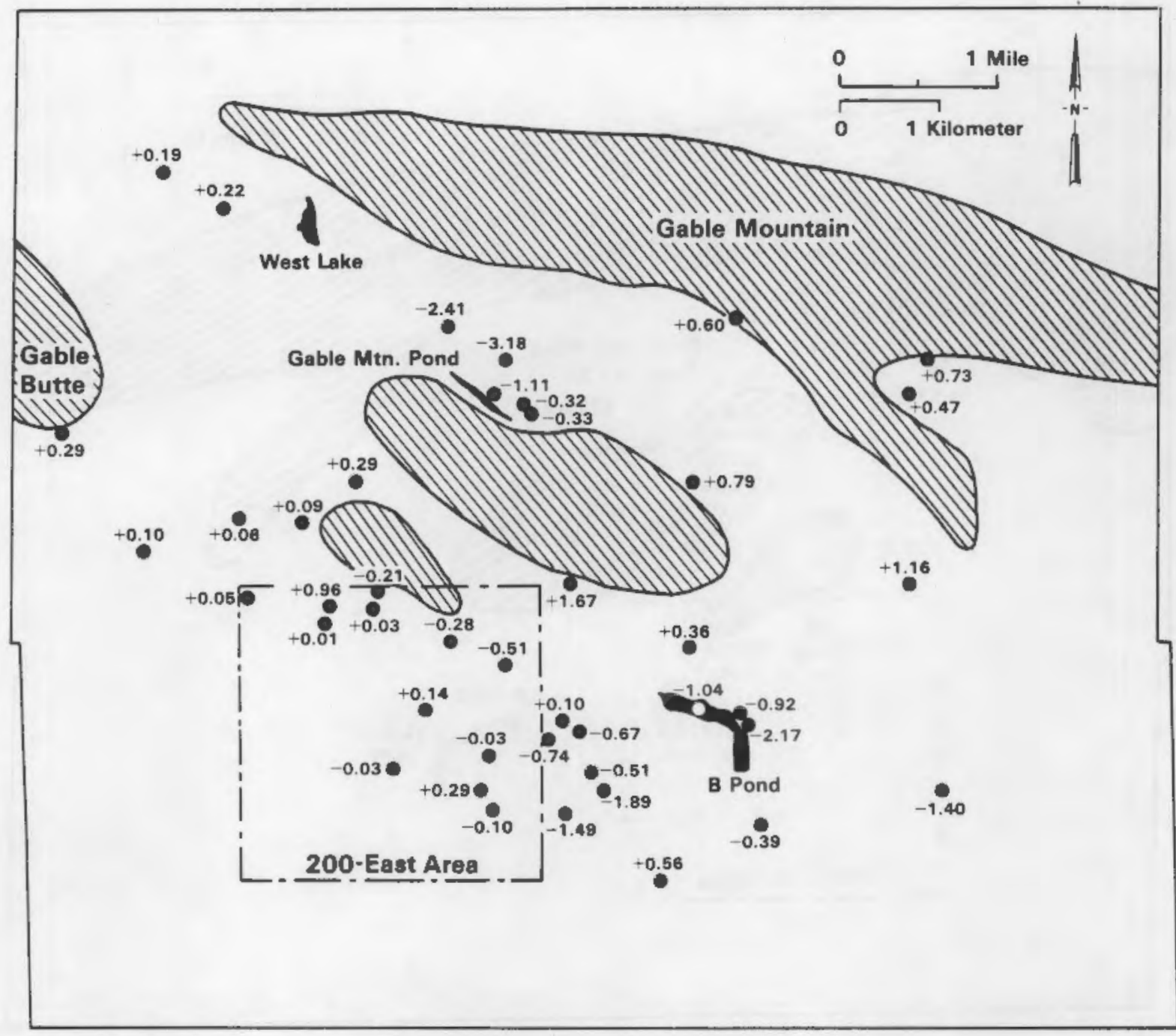

Numbers are in Feet Above Mean Sea Level

$+\quad$ Rise in Water Table Elevation

- Decrease in Water Table Elevation

- Wells Used in Preparation of Map

Ponds

DIV Estimated Basalt Outerops Above Water Table (Graham, Last and Fecht 1984)

FIGURE 4. Changes in the Water Table Elevations from December 1985 to December 1986 

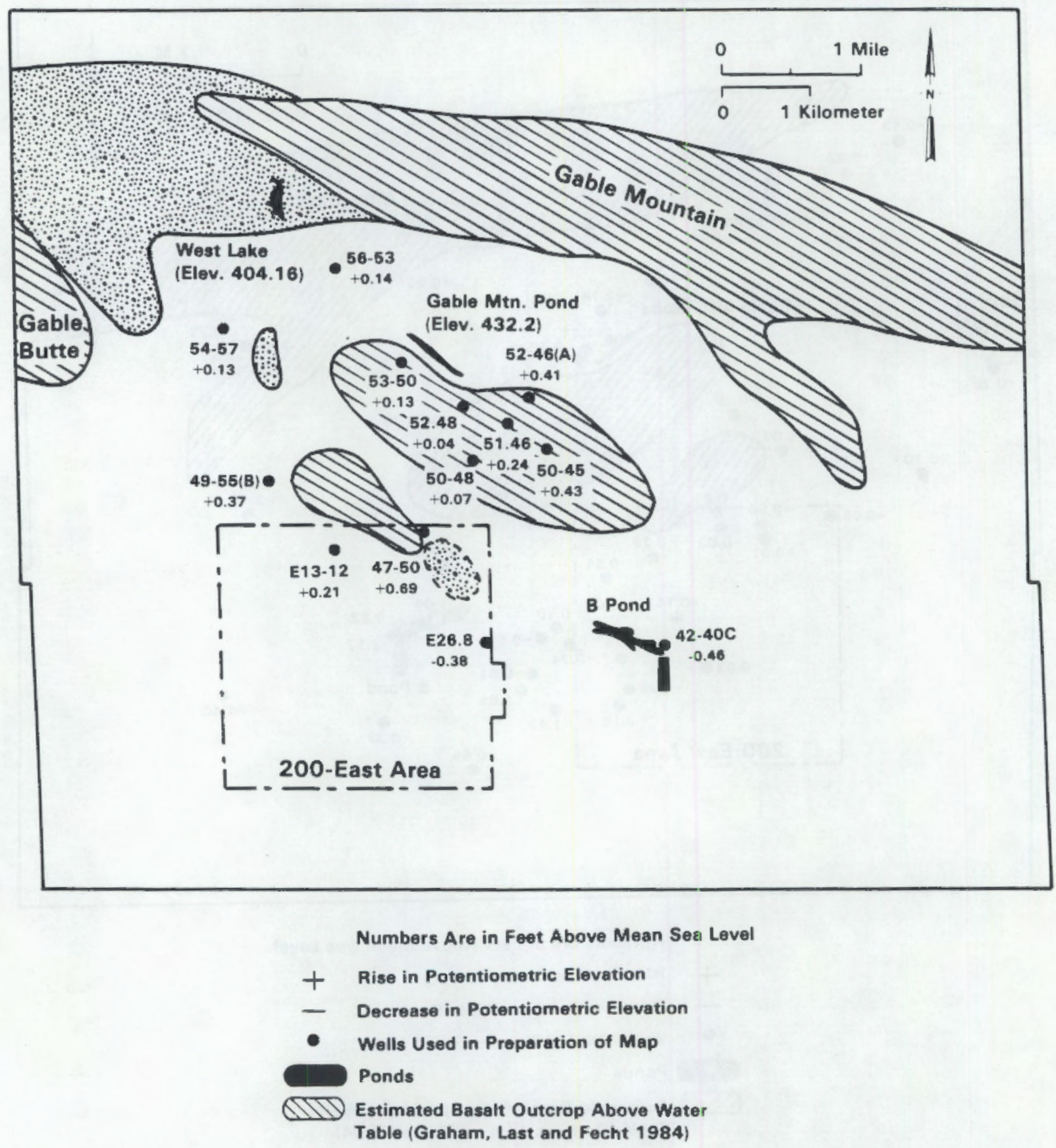

FIGURE 5. Changes in the Potentiometric Elevations from December 1985 to December 1986 in the Rattlesnake Ridge Aquifer 


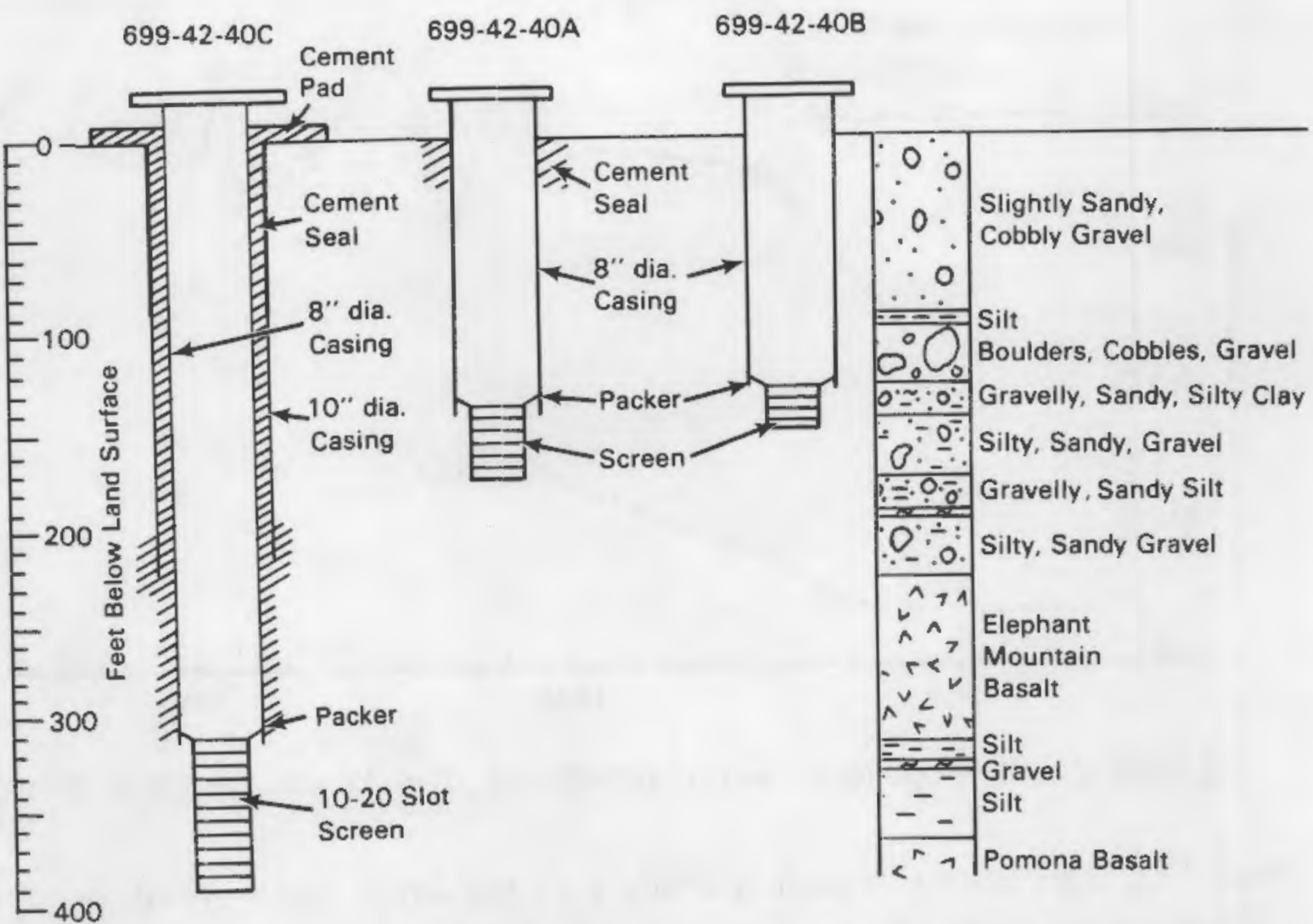

FIGURE 6. Construction Diagrams and Geology of Wells 699-42-20A, 699-42-40B, and $699-42-40 \mathrm{C}$

hydraulic heads in the confined and unconfined aquifers. (a) Graham, Last and Fecht (1984) concluded that direct communication between the unconfined and Rattlesnake Ridge aquifers occurs as a result of erosional "windows" through the confining bed (Elephant Mountain Basalt). These areas of erosion were identified north and west of $B$ Pond. Leakage between the aquifers may also occur through fractures in the Elephant Mountain Basalt. The water level fluctuations in the well completed in the Rattlesnake Ridge aquifer near B Pond (well 699-42-40C; Figure 7) appear to be the result of changes in leakage from the fluctuating B Pond mound in the unconfined aquifer (wells 699-42-40A and B;

(a) 1986 data from G. V. Last, M. A. Young, T. L. Liikala and E. J. Jensen of Pacific Northwest Laboratory, Richland, Washington, as a result of their research on the water level changes beneath the Separations Areas of the Hanford Site. 


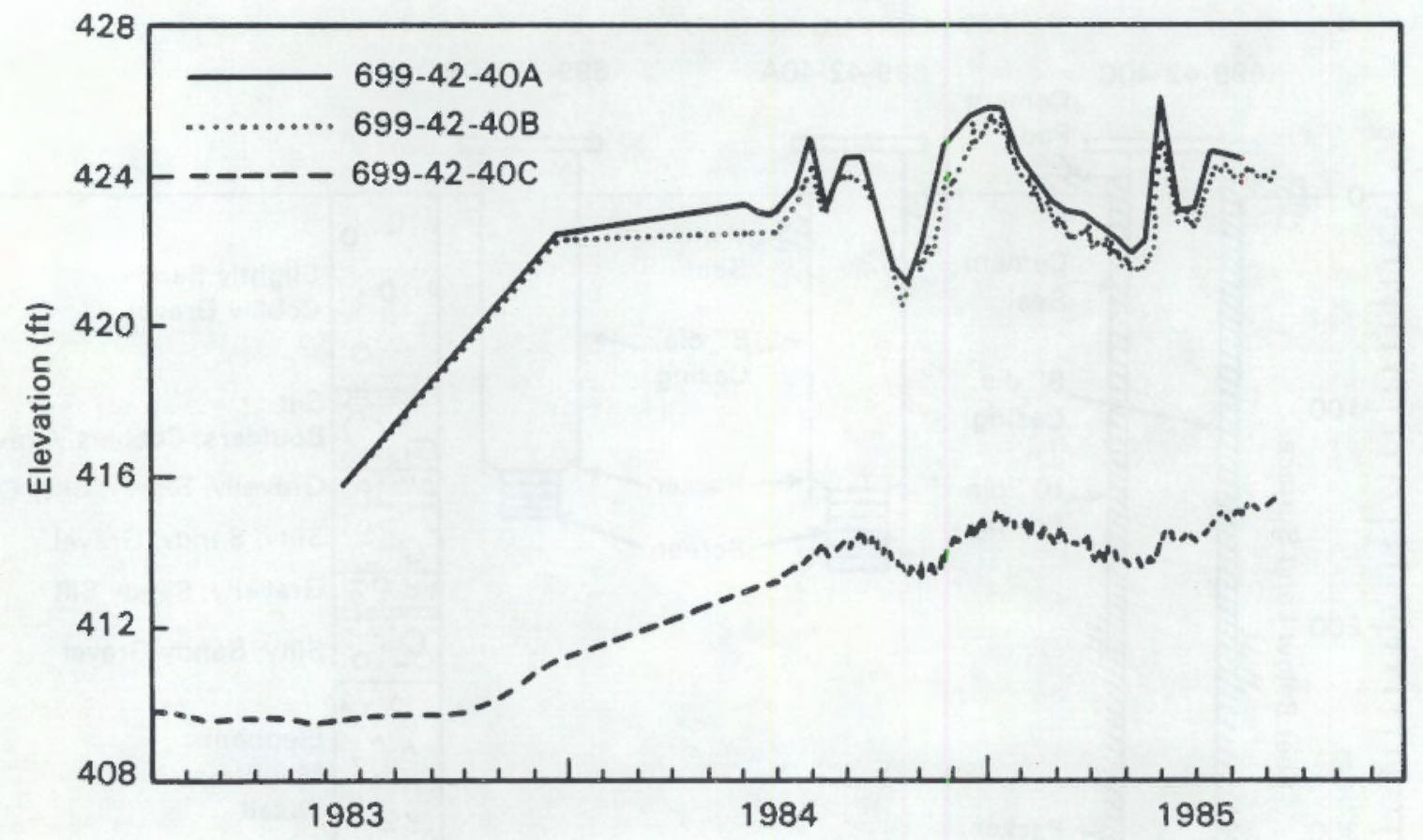

FIGURE 7. Hydrograph of Wells 699-42-40A, 699-42-40B, and 699-42-40C

Figure 7). The higher frequency changes in the water table elevation ( 1 to 2 months) do not result in a response in the Rattlesnake Ridge aquifer, whereas the lower frequency changes ( $>2$ months) are propagated to the confined aquifer. This dampening of response is a result of the vertical hydraulic conductivity and thickness of the confining bed.

Estimates of this leakage from the unconfined to the confined aquifer can be made with calibrated flow models. The flux through the bottom of the unconfined aquifer has not been considered in the ground-water models of the Hanford site. This component of water balance could prove to be significant. Additional insight into leakage could be gained through stable isotope analyses of the ground waters. 


\section{CHEMICAL ANALYSIS}

In addition to hydraulic head data, ground-water samples were collected from the Rattlesnake Ridge and unconfined aquifers. The samples from both aquifers were analyzed for tritium, nitrate, cobalt-60, cesium-137, and ruthenium-106 by U.S. Testing Company, Inc., Richland, Washington. Tritium, nitrate, and ruthenium were chosen for this study because their poor ionexchange characteristics cause them to be more readily transported in the ground water than the other constituents; these ions move through the ground water at approximately the same rate as water, which makes them good tracers for ground-water movement. Cobalt and cesium were chosen because of their abundance in the separations areas' liquid waste, which is being discharged to the ground (Law and Schatz 1986). Their presence in the ground-water demonstrates a direct interaction between the ground water and the liquid wastes. However, these two constituents are poor tracers because they have good ionexchange characteristics, which make them less mobile in the ground water (Prater et al. 1984).

The map in Figure 8 illustrates the average tritium concentrations in the unconfined aquifer from August to November 1986. The Rattlesnake Ridge aquifer was sampled during the week of September 8-14, 1986, using the wells and sampling devices listed in Table 1 . The concentrations in $\mathrm{pCi} / \mathrm{L}$, given beside each well number in Figure 8, may be compared to data from the confined aquifer in Tables 2 through 7. All the wells listed in Table 1 are completed in the Rattlesnake Ridge aquifer, except well 699-\$16-24, which is completed in the Mabton interbed. The Mabton interbed is located below the Pomona Basalt and has hydraulic properties very similar to the Rattlesnake Ridge interbed. Wells 299-E33-12 and 699-47-50, located near the northeast corner of the 200-East Area, contain small amounts of tritium and nitrate. Well 699-42-40C, near $B$ Pond, contains an insignificant level of tritium, and no other contaminants were detected (Table 2). The remaining Rattlesnake Ridge wells were below detection 1 imits for tritium, nitrate, cobalt-60, cesium-137, and ruthenium-106 (Tables 2 through 7 ). 


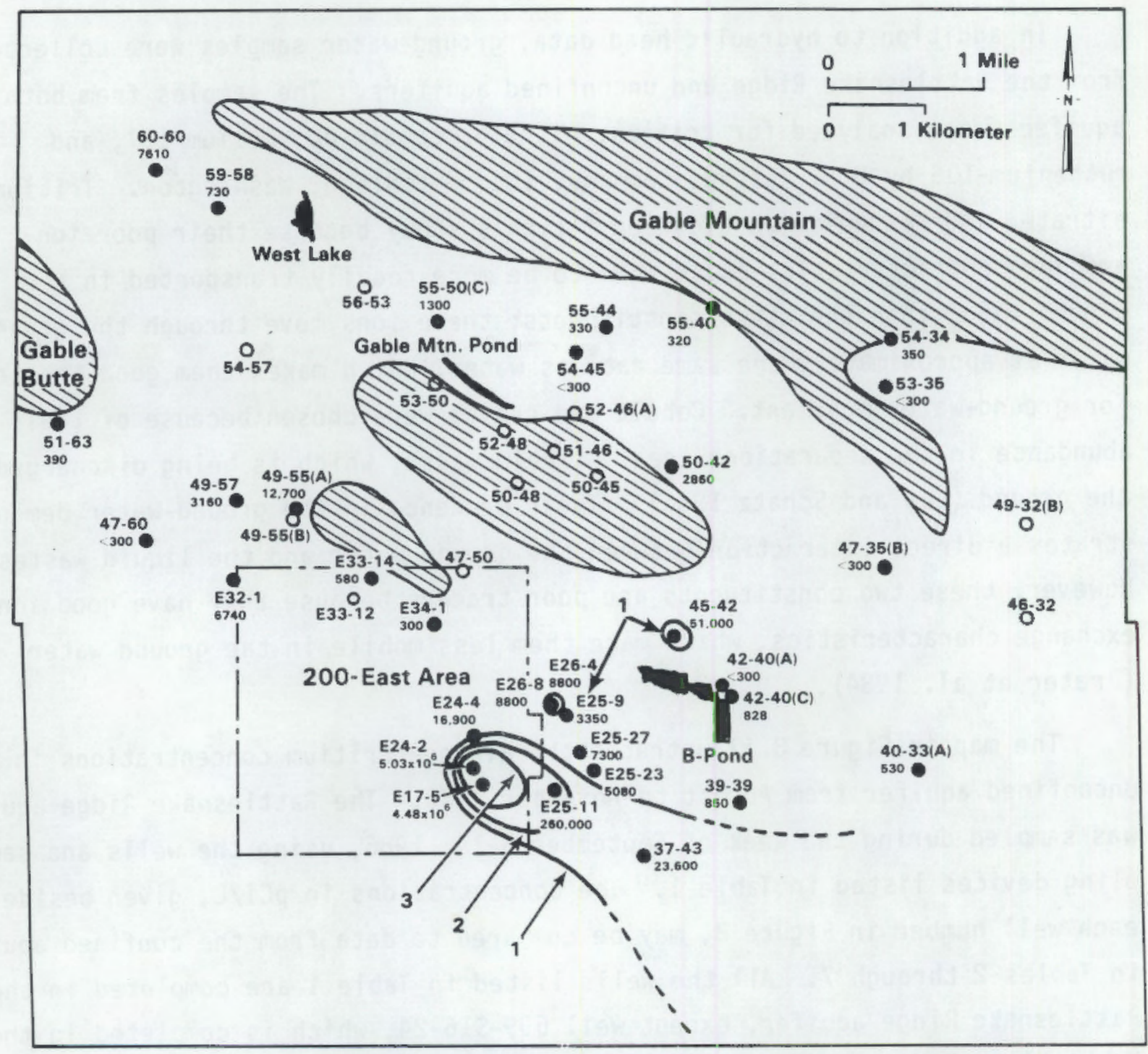

1, $20,000 \mathrm{pCi} / \mathrm{L}$ :

2, $200,000 \mathrm{pCi} / \mathrm{L}$;

3, $2,000,000 \mathrm{pCi} / \mathrm{L}$

Wells in the Unconfined

Aquifer That Were Sampled for Tritium

- Wells in the Rattlesnake Fidge Confined Aquifer

FIGURE 8. Unconfined Aquifer, Average Tritium Concentrations for August, September, October, and November 1986 
TABLE 1. Wells Used to Sample the Rattlesnake Ridge Aquifer

\begin{tabular}{|c|c|c|c|c|}
\hline $\begin{array}{l}\text { We } 11 \\
\text { Number }\end{array}$ & $\begin{array}{l}\text { Depth to } \\
\text { water (ft) }\end{array}$ & $\begin{array}{c}\text { Casing } \\
\text { Diameter (in.) }\end{array}$ & $\begin{array}{l}\text { Sampling } \\
\text { Method } \\
\end{array}$ & $\begin{array}{l}\text { EMA Number } \\
\text { (Well] Code) }\end{array}$ \\
\hline $199-B 3-2 P$ & 38.00 & 1.5 & Bailer & 1856 \\
\hline $199-\mathrm{H} 4-2$ & 0.00 & 2.0 & Valve & 1876 \\
\hline $299-E 26-08$ & 197.00 & 8.0 & Pump & 2558 \\
\hline $299-£ 33-12$ & 216.91 & 6.0 & Pump & 2559 \\
\hline $699-20-E 5 P$ & 80.00 & 1.5 & Air lift & 4705 \\
\hline $699-20-£ 50$ & 99.00 & 1.5 & Air lift & 4706 \\
\hline $699-22-70 P$ & 184.77 & 1.5 & Baiter & 4673 \\
\hline $699-24-1 P$ & 88.00 & 1.5 & Air lift & 4710 \\
\hline $699-42-40 C$ & 131.00 & 8.0 & Pump & 4912 \\
\hline $699-46-32$ & 60.00 & 6.0 & Pump & 4908 \\
\hline $699-47-50$ & 177.00 & 6.0 & Pump & 4913 \\
\hline 699-49-3२B & 105.00 & 6.0 & Pump & 4909 \\
\hline $699-49-55 B$ & 124.61 & 8.0 & Pump & 4910 \\
\hline $699-50-45$ & 43.00 & 6.0 & Pump & 4914 \\
\hline $699-50-48$ & 142.00 & 6.0 & Pump & 4883 \\
\hline $699-51-46$ & 36.00 & 8.0 & Pump & 4915 \\
\hline $699-52-46 A$ & 47.00 & 8.0 & Pump & 4916 \\
\hline $699-52-48$ & 58.00 & 8.0 & Pump & 4917 \\
\hline $699-53-50$ & 38.00 & 8.0 & Pump & 4918 \\
\hline $699-54-57$ & 172.00 & 6.0 & Pump & 4919 \\
\hline $699-56-53$ & 30.00 & 8.0 & Pump & 4920 \\
\hline $699-S 16-24$ & 132.04 & 2.0 & Air $1 \mathrm{ift}$ & 4911 \\
\hline
\end{tabular}


TABLE 2. Tritium Concentrations in the Rattlesnake Ridge Aquifer

\begin{tabular}{|c|c|c|c|}
\hline $\begin{array}{c}\text { We } 11 \\
\text { Number }\end{array}$ & $\begin{array}{c}\text { Collection } \\
\text { Date } \\
\end{array}$ & Less $\operatorname{Than}(\mathrm{a})$ & $\begin{array}{c}\text { Analysis } \\
\text { value }\end{array}$ \\
\hline $1-B 3-2 P$ & $9 / 12 / 86$ & & $3.2500 E+02$ \\
\hline $1-\mathrm{H} 4-2$ & $9 / 10 / 86$ & $<$ & $-6.7600 \mathrm{E}+01$ \\
\hline $2-E 26-8$ & $9 / 08 / 86$ & $<$ & $-3.8500 E+01$ \\
\hline $2-E 33-12$ & $9 / 11 / 86$ & & $3.9000 E+02$ \\
\hline $6-20-E 5 A P$ & $9 / 09 / 86$ & $<$ & $-1.3300 E+02$ \\
\hline $6-20-E 5 A Q$ & $9 / 09 / 86$ & $<$ & $-4.3900 E+01$ \\
\hline $6-22-70 P$ & $9 / 12 / 86$ & $<$ & $-1.7200 E+01$ \\
\hline $6-24-1 P$ & $9 / 09 / 86$ & $<$ & $2.8300 E+01$ \\
\hline $6-42-40 \mathrm{C}$ & $9 / 09 / 86$ & & $3.1300 E+02$ \\
\hline $6-46-32$ & $9 / 10 / 86$ & $<$ & $1.3200 E+01$ \\
\hline $6-47-50$ & $9 / 09 / 86$ & & $3.7200 E+02$ \\
\hline $6-49-32 B$ & $9 / 10 / 86$ & $<$ & $6.0600 E+01$ \\
\hline $6-49-55 B$ & $9 / 09 / 86$ & $<$ & $-2.4500 E+02$ \\
\hline $6-50-45$ & $9 / 10 / 86$ & $<$ & $-5.4600 E+01$ \\
\hline $6-50-48 B$ & $9 / 09 / 86$ & $<$ & $-9.1300 E+01$ \\
\hline $6-51-46$ & $9 / 10 / 86$ & $<$ & $-6.6800 E+01$ \\
\hline $6-52-46 A$ & $9 / 10 / 86$ & $<$ & $-6.0300 E+01$ \\
\hline $6-52-48$ & $9 / 10 / 86$ & $<$ & $4.0900 E+07$ \\
\hline $6-53-50$ & $9 / 11 / 86$ & $<$ & $-1.2900 E+02$ \\
\hline $6-54-57$ & $9 / 08 / 86$ & $<$ & $1.5900 E+02$ \\
\hline $6-56-53$ & $9 / 11 / 86$ & $<$ & $9.6900 \mathrm{E}+00$ \\
\hline $6-S 16-24$ & $9 / 12 / 86$ & $<$ & $3.2300 E+0$ \\
\hline
\end{tabular}

(a) A "less than" sign (<) means that the magnitude of the analysis result is less than the counting error. 
IABLE 3. Nitrate Concentrations in the Rattlesnake Ridge Aquifer

\begin{tabular}{|c|c|c|}
\hline $\begin{array}{l}\text { Well } 1 \\
\text { Number }\end{array}$ & $\begin{array}{c}\text { Collection } \\
\text { Date } \\
\end{array}$ & $\begin{array}{c}\text { Analysis } \\
\text { Value }\end{array}$ \\
\hline $1-B 3-2 P$ & $9 / 12 / 86$ & $2.0000 \mathrm{E}-01$ \\
\hline $1-H 4-2$ & $9 / 10 / 86$ & $4.1000 E-01$ \\
\hline $2-E 26-8$ & $9 / 08 / 86$ & $5.0000 \mathrm{E}-01$ \\
\hline $2-E 33-12$ & $9 / 11 / 86$ & $4.9100 E+00$ \\
\hline $6-20-E 5 A P$ & $9 / 09 / 86$ & $1.2700 E+00$ \\
\hline $6-20-E 5 A Q$ & $9 / 09 / 86$ & $3.3000 E-01$ \\
\hline $6-22-70 P$ & $9 / 12 / 86$ & $2.0000 E-01$ \\
\hline $6-24-1 P$ & $9 / 09 / 86$ & $1.6000 \mathrm{E}-01$ \\
\hline $6-42-40 C$ & $9 / 09 / 86$ & $3.3000 E-01$ \\
\hline $6-46-32$ & $9 / 10 / 86$ & $6.7000 \mathrm{E} \rightarrow 01$ \\
\hline $6-47-50$ & $9 / 09 / 86$ & $5.6800 E+00$ \\
\hline $6-49-32 B$ & $9 / 10 / 86$ & $6.6000 E-01$ \\
\hline $6-49-55 B$ & $9 / 09 / 86$ & $7.5000 \mathrm{E}-01$ \\
\hline $6-50-45$ & $9 / 10 / 86$ & $5.0000 E-01$ \\
\hline $6-50-48 B$ & $9 / 09 / 86$ & $5.0000 \mathrm{E}-01$ \\
\hline $6-51-46$ & $9 / 10 / 86$ & $6.6000 E-01$ \\
\hline $6-52-46 A$ & $9 / 10 / 86$ & $1.4500 E+00$ \\
\hline $6-52-48$ & $9 / 10 / 86$ & $1.6000 \mathrm{E}-01$ \\
\hline $6-53-50$ & $9 / 11 / 86$ & $3.3000 \mathrm{E}-01$ \\
\hline $6-54-57$ & $9 / 08 / 86$ & $1.1800 E+00$ \\
\hline $6-56-53$ & $9 / 11 / 86$ & $6.6000 \mathrm{E}-01$ \\
\hline $6-516-24$ & $9 / 12 / 86$ & $2.0000 E-01$ \\
\hline
\end{tabular}


TABLE 4. Cobalt-60 Concentrations in the Rattlesnake Ridge Aquifer

\begin{tabular}{|c|c|c|c|}
\hline $\begin{array}{l}\text { Well } 1 \\
\text { Number }\end{array}$ & $\begin{array}{c}\text { Collection } \\
\text { Date }\end{array}$ & Less Than (a) & $\begin{array}{c}\text { Analysis } \\
\text { Value }\end{array}$ \\
\hline $1-B 3-2 P$ & $9 / 12 / 86$ & $<$ & $3.0400 E+00$ \\
\hline $1-\mathrm{H} 4-2$ & $9 / 10 / 86$ & & $8.0200 E+00$ \\
\hline $2-E 26-8$ & $9 / 08 / 86$ & $<$ & $-3.5000 E+00$ \\
\hline 2-E33-12 & $9 / 11 / 86$ & & $1.9600 E+01$ \\
\hline $6-20-E 5 A P$ & $9 / 09 / 86$ & $<$ & $2.2500 E+00$ \\
\hline $6-20-E 5 A Q$ & $9 / 09 / 86$ & $<$ & $3.0300 E+00$ \\
\hline $6-22-70 \mathrm{P}$ & $9 / 12 / 86$ & $<$ & $2.2600 E+00$ \\
\hline $6-24-1 P$ & $9 / 09 / 86$ & $<$ & $1.0700 E+00$ \\
\hline $6-42-40 C$ & $9 / 09 / 86$ & $<$ & $-3.3400 E+00$ \\
\hline $6-46-32$ & $9 / 10 / 86$ & $<$ & $-1.2600 E+01$ \\
\hline $6-47-50$ & $9 / 09 / 86$ & $<$ & $4.0400 E+00$ \\
\hline $6-49-32 B$ & $9 / 10 / 86$ & $<$ & $-4.6800 E+00$ \\
\hline $6-49-55 B$ & $9 / 09 / 86$ & $<$ & $-6.2000 E+00$ \\
\hline $6-50-45$ & $9 / 10 / 86$ & $<$ & $-2.6700 E+00$ \\
\hline $6-50-48 B$ & $9 / 09 / 86$ & $<$ & $2.0200 E+00$ \\
\hline $6-51-46$ & $9 / 10 / 86$ & & $7.8800 E+00$ \\
\hline $6-52-46 A$ & $9 / 10 / 86$ & $<$ & $3.0300 E+00$ \\
\hline $6-52-48$ & $9 / 10 / 86$ & $<$ & $-4.6800 E+00$ \\
\hline $6-53-50$ & $9 / 11 / 86$ & $<$ & $-2.5200 E+01$ \\
\hline $6-54-57$ & $9 / 08 / 86$ & $<$ & $1.1300 E+00$ \\
\hline $6-56-53$ & $9 / 11 / 86$ & & $9.5900 E+00$ \\
\hline $6-516-24$ & $9 / 12 / 86$ & $<$ & $3.2100 E+00$ \\
\hline
\end{tabular}

(a) A "less than" sign (<) means that the magnitude of the analysis result is less than the counting error. 
TABLE 5. Cesium-137 Concentrations in the Rattlesnake Ridge Aquifer

\begin{tabular}{|c|c|c|c|}
\hline $\begin{array}{l}\text { We11 } \\
\text { Number }\end{array}$ & $\begin{array}{c}\text { Collection } \\
\text { Date }\end{array}$ & Less $\operatorname{Than}(a)$ & $\begin{array}{c}\text { Analysis } \\
\text { Value }\end{array}$ \\
\hline $1-B 3-2 P$ & $9 / 12 / 86$ & $<$ & $3.2000 \mathrm{E}-01$ \\
\hline $1-\mathrm{H} 4-2$ & $9 / 10 / 86$ & $<$ & $-1.6500 E+00$ \\
\hline $2-E 26-8$ & $9 / 08 / 86$ & $<$ & $-2.9900 E+0 C$ \\
\hline $2-E 33-12$ & $9 / 11 / 86$ & & $7.2600 E+0 C$ \\
\hline $6-20-E 5 A P$ & $9 / 09 / 86$ & $<$ & $4.4700 E+0 C$ \\
\hline $6-20-E 5 A Q$ & $9 / 09 / 86$ & $<$ & $2.2400 E+0 C$ \\
\hline $6-22-70 P$ & $9 / 12 / 86$ & $<$ & $-4.1300 E+0 C$ \\
\hline $6-24-1 P$ & $9 / 09 / 86$ & $<$ & $-3.0000 E+0 C$ \\
\hline $6-42-40 C$ & $9 / 09 / 86$ & $<$ & $-9.4800 E+0 C$ \\
\hline $6-46-32$ & $9 / 10 / 86$ & $<$ & $2.1400 E+0 C$ \\
\hline $6-47-50$ & $9 / 09 / 86$ & $<$ & $-3.1900 \mathrm{E}-01$ \\
\hline $6-49-32 B$ & $9 / 10 / 86$ & $<$ & $-7.8300 E+00$ \\
\hline $6-49-55 B$ & $9 / 09 / 86$ & $<$ & $-5.1600 E+00$ \\
\hline $6-50-45$ & $9 / 10 / 86$ & $<$ & $-1.6600 E+00$ \\
\hline $6-50-48 B$ & $9 / 09 / 86$ & $<$ & $3.5100 E+0 C$ \\
\hline $6-51-46$ & $9 / 10 / 86$ & & $3.4400 E+0 C$ \\
\hline $6-52-46 A$ & $9 / 10 / 86$ & $<$ & $2.2400 E+0 C$ \\
\hline $6-52-48$ & $9 / 10 / 86$ & $<$ & $-4.1200 E-01$ \\
\hline $6-53-50$ & $9 / 11 / 86$ & $<$ & $-1.1100 E+01$ \\
\hline $6-54-57$ & $9 / 08 / 86$ & & $3.4400 E+0 C$ \\
\hline $6-56-53$ & $9 / 11 / 86$ & $<$ & $3.6600 \mathrm{E}+0 \mathrm{C}$ \\
\hline $6-516-24$ & $9 / 12 / 86$ & $<$ & $1.3300 \mathrm{E}+0 \mathrm{C}$ \\
\hline
\end{tabular}

(a) A "less than" sign ( $<$ ) means that the magnitude of the analysis result is less than the counting error. 
TABLE 6. Ruthenium-106 Concentrations in the Rattlesnake Ridge Aquifer

\begin{tabular}{|c|c|c|c|}
\hline $\begin{array}{c}\text { Well } \\
\text { Number }\end{array}$ & $\begin{array}{c}\text { Collection } \\
\text { Date } \\
\end{array}$ & Less Than $(a)$ & $\begin{array}{c}\text { Analysis } \\
\text { Value }\end{array}$ \\
\hline $1-B 3-2 P$ & $9 / 12 / 86$ & $<$ & $2.6700 \mathrm{E}+00$ \\
\hline $1-H 4-2$ & $9 / 10 / 86$ & & $1.0200 E+10$ \\
\hline $2-E 26-8$ & $9 / 08 / 86$ & $<$ & $1.7800 E+01$ \\
\hline $2-E 33-12$ & $9 / 11 / 86$ & $<$ & $-1.3800 E+02$ \\
\hline $6-20-E 5 A P$ & $9 / 09 / 86$ & $<$ & $-3.4500 E+01$ \\
\hline $6-20-E 5 A Q$ & $9 / 09 / 86$ & $<$ & $2.3800 E+01$ \\
\hline $6-22-70 P$ & $9 / 12 / 86$ & $<$ & $2.6200 E+01$ \\
\hline $6-24-19$ & $9 / 09 / 86$ & $<$ & $-5.8100 E+01$ \\
\hline $6-42-40 c$ & $9 / 09 / 86$ & $<$ & $-3.0800 E+01$ \\
\hline $6-46-32$ & $9 / 10 / 86$ & $<$ & $-2.1300 E+01$ \\
\hline $6-47-50$ & $9 / 09 / 86$ & $<$ & $-2.3800 E+01$ \\
\hline $6-49-32 B$ & $9 / 10 / 86$ & & $3.7500 E+01$ \\
\hline $6-49-55 B$ & $9 / 09 / 86$ & $<$ & $-4.6000 E+01$ \\
\hline $6-50-45$ & $9 / 10 / 86$ & $<$ & $-2.2100 E+01$ \\
\hline $6-50-48 B$ & $9 / 09 / 86$ & $<$ & $2.3800 E+01$ \\
\hline $6-51-46$ & $9 / 10 / 86$ & & $5.7400 E+00$ \\
\hline $6-52-46 A$ & $9 / 10 / 86$ & $<$ & $-4.7500 E+01$ \\
\hline $6-52-48$ & $9 / 10 / 86$ & & $5.4600 E+01$ \\
\hline $6-53-50$ & $9 / 11 / 86$ & & $-4.6100 \mathrm{E}+01$ \\
\hline $6-54-57$ & $9 / 08 / 86$ & $<$ & $1.4400 E+01$ \\
\hline $6-56-53$ & $9 / 11 / 86$ & $<$ & $-1.3800 E+01$ \\
\hline $6-516-24$ & $9 / 12 / 86$ & $<$ & $-7.2700 E+01$ \\
\hline
\end{tabular}

(a) A "less than" sign (<) means that the magnitude of the analysis is less than the counting error. 
TABLE 7. Tritium Concentrations in well 699-42-40C

\begin{tabular}{|c|c|c|c|}
\hline $\begin{array}{l}\text { Well } \\
\text { Number }\end{array}$ & $\begin{array}{c}\text { Collection } \\
\text { Date } \\
\end{array}$ & Less $\operatorname{Than}(\mathrm{a})$ & $\begin{array}{c}\text { Analysis } \\
\text { Value }\end{array}$ \\
\hline $6-42-40 C$ & $6 / 25 / 84$ & & $-7.4000 E+01$ \\
\hline $6-42-40 C$ & $4 / 21 / 86$ & $<$ & $1.1300 E+02$ \\
\hline $6-42-40 C$ & $9 / 09 / 86$ & & $3.1300 E+02$ \\
\hline $6-42-40 c$ & $10 / 27 / 86$ & $<$ & $1.7000 E+02$ \\
\hline
\end{tabular}

(a) A "less than" sign (<) means that the magnitude of the analysis is less than the counting error.

The tritium and nitrate in the confined aquifer at well 299-E33-12 are attributed to a high-salt, dense waste that migrated by density flow into the well when it was open to the unconfined aquifer (Graham, Last and Fecht 1984). This well has since been sealed from the unconfined aquifer by installing a liner in the well and grouting the annular space from the Elephant Mountain Basalt to the surface. This remedial action was taken by Rockwell Hanford Operations in 1982.

We11 699-47-50 is located near a postulated erosional window of the Elephant Mountain Basalt (Figure 2). The tritium and nitrate in this well have resulted from aquifer intercommunication (Graham, Last and Fecht 1984).

The tritium in well 699-42-40C appears to have increased since the well was drilled in 1982, but the analytical techniques used by Graham, Last and Fecht (1984) in 1982 were much more sensitive than those used in this study. Table 7 shows four samples analyzed by U.S. Testing Company, Inc. after 1982. of these samples, only one has a tritium concentration that is slightly above the detection limit. 


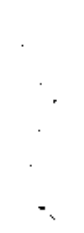




\section{CONCLUSIONS}

The elevation of the water table in the unconfined aquifer decreased slightly in the southeast corner of the 200-East Area, around B Pond, and near Gable Mountain Pond from Oecember 1985 to December 1986. There was a slight increase in elevation of the water table over the rest of the B Pond - Gable Mountain Pond area during that time.

A decrease in elevation of the potentiometric surface of the Rattiesnake Ridge aquifer occurred around B Pond from December 1985 to December 1986. This surface rose in all other wells measured in the study area during that time.

Analysis of chemical constituents in the Rattlesnake Ridge aquifer demonstrates that communication between the unconfined and confined aquifers has occurred, although the levels of contaminants found in the Rattlesnake Ridge aquifer during this study are below DOE Oerived Concentration Guides. (a) Because erosion of the Elephant Mountain Basalt and the Rattlesnake Ridge interbed near West Lake has allowed the Rattlesnake Ridge aquifer to discharge to the unconfined aquifer, these constituents will eventually discharge back to the unconfined aquifer in that vicinity (Graham, Last and Fecht 1984).

(a) Concentrations of radionuclides in water and air that could be continuously consumed or inhaled, respectively, and not exceed an effective dose equivalent of $100 \mathrm{mrem} / \mathrm{yr}$ (PNL 1987). 


\section{DATA UNCERTAINTIES}

Some data uncertainties became apparent as this study progressed. These uncertainties are explained here to clarify the results obtained from this study. During this study it became apparent that several wells needed resurveying or new completion zones. These remedial actions would be used to better define the potentiometric surface and characteristics of the Rattlesnake Ridge aquifer near the 2D0-East Area.

The following wells need to be resurveyed: 699-54-45A, 699-54-49, 699-55-44, 699-46-32, and 699-49-32B. Wel1s 699-54-45A and 699-55-44 have water table elevations in the unconfined aquifer that are suspiciously low. Well 699-54-49, also completed in the unconfined aquifer, has never been surveyed. Accurate casing elevations of these wells are needed to obtain greater definition of the contours around Gable Mountain Pond. Wells 699-46-32 and 699-49-32B were drilled to the Pomona Basalt by Golder and Associates of Bellevue, Washington, in 1982 and left uncompleted. In August 1986, Pacific Northwest Laboratory (PNL) completed these two wells by installing a 20-slot screen over the entire thickness of the Rattlesnake Ridge aquifer. As a result, the casings have been moved to new elevations, so the old survey data may no longer be valid. If the casing elevations of these two wells are valid, then a flow boundary must exist somewhere between well 699-42-40C and well 69946-32 (Figure 2). This would also change our concept of flow directions in the Rattlesnake Ridge aquifer to the east of B Pond. After this surveying is completed, more wells may need to be drilled or some old wells deepened to the east of $B$ Pond to clarify this issue.

In September 1980, Rockwell Hanford Operations drilled well 699-54-458. This well apparently was completed within the Elephant Mountain Basalt. The screen is set in $5 \mathrm{ft}$ of basalt and $10 \mathrm{ft}$ of clay. The static head is at $460 \mathrm{ft}$ above mean sea level. The pieziometric surface of the Rattlesnake Ridge aquifer in this area is $410 \mathrm{ft}$ above mean sea level. The short interval of clay around the screen in this well may be acting as a one-way valve by letting water go up the pipe column, but not letting it back down. To resolve this 
problein, the screen should be pulled and the well drilled through the Rattlesnake Ridge interbed to the Pomona Basalt with 4-in. casing. After the exact location of the stratigraphic layers has been determined, a screen can be installed across the entire length of the Rattlesnake Ridge aquifer. The proper completion of this well will give a better definition of the Rattlesnake Ridge aquifer. A similar type of reconstruction should also be considered for well 299-E16-1, which is completed in between the Elephant Mountain 1 and Elephant Mountain 2 basalt units.

Barometric efficiency and stable isotope studies of the wells completed in the confined aquifer may be useful in determining whether direct communication or local pressure changes are responsible for the fluctuations in elevation of the pieziometric surface. This could be accomplished by comparing data on barometric efficiencies and stable isotopes to those of Graham, Last and Fecht (1984). 


\section{REFERENCES}

Brown, D. J. 1959. Subsurface Geology of the Hanford Separations Area. HW-61780, General Electric Company, Richland, Washington.

DOE. 1982. Site Characterization Report for the Basalt Waste Isolation Project. Three volumes. DOE/RL 82-3. Prepared by Rockwell Hanford Operations for the U.S. Department of Energy, Richland, Washington.

Fecht, K. R. 1978. Geology of the Gable Mountain Gable Butte Area. RHO-BWI-LD-5, Rockwe11 Hanford Operations, Richland, Washington.

Graham, M. J., G. V. Last and K. R. Fecht. 1984. An Assessment of Aquifer Intercommunication in the B Pond - Gable Mountain Pond Area of the Hanford Site. RHO-RE-ST-12P, Rockwell Hanford Operations, Richland, Washington.

Jensen, E. J., A. L. Schatz and T. L. Liikala. 1985. Unconfined Aquifer and Rattlesnake Ridge Aquifer Water-Level Measurements Data Maps. RH0-2-38396, Rev. 20, Rockwell Hanford Operations, Richiand, Washington.

Law, A. G., and A. L. Schatz. 1986. Results of the Separations Area GroundWater Monitoring Network for 1985. RHO-RE-SR-86-24P, Rockwell Hanford Operations, Richland, Washington.

Myers, C. H., and S. M. Price, eds. 1981. Subsurface Geology of the Cold Creek Syncline. RHO-BWI-ST-14, Rockwell Hanford Operations, Richland, Washington.

Myers, C.W./S. M. Price et al. 1979. Geologic Studies of the Columbia Plateau: A Status Report. RHO-BWI-ST-4, Rockwell Hanford Operations, Richland, Washington.

Prater, L. S., J. T. Rieger, C. S. Cline, E. J. Jensen, T. L. Liikala and K. R. Oster. 1984. Ground-Water Surveillance at the Hanford Site for CY 1983. PNL-5041, Pacific Northwest Laboratory, Richtand, Washington.

PNL. 1987. Environmental Monitoring at Hanford for 1985. PNL-5817, Pacific Northwest Laboratory, Richland, Washington.

Tallman, A. M., K. R. Fecht, M. C. Mavratt and G. V. Last. 1979. Geology of the Separations Areas, Hanford Site, South-Central Washington. RH̄O-ST-23, Rockwell Hanford Operations, Richland, Washington. 
-

$\therefore$

$i$ 
APPENDIX A

HANFORD WATER LEVEL MEASUREMENTS 
TABLE A.1. Hanford Water Level Measurements in Unconfined Aquifer, December 1986

\begin{tabular}{|c|c|c|c|c|}
\hline Wel 1 Number & Date & $\begin{array}{l}\text { Depth to } \\
\text { Water }(f t)\end{array}$ & $\begin{array}{c}\text { Elevation } \\
\text { to Water ( } f t) \\
\end{array}$ & $\begin{array}{l}\text { Elevation } \\
\text { of Casing }\end{array}$ \\
\hline 299-E 17-05 & $12 / 18 / 86$ & 313.92 & 404.73 & 718.65 \\
\hline $299-E 23-01$ & $12 / 18 / 86$ & 304.05 & 405.60 & 709.65 \\
\hline 299-E24-02 & $12 / 18 / 86$ & 312.09 & 405.10 & 717.19 \\
\hline $299-E 24-04$ & $12 / 18 / 86$ & 291.32 & 405.68 & 697.00 \\
\hline 299-E25-04 & $12 / 17 / 86$ & 252.79 & 406.60 & 659.39 \\
\hline 299-E25-09 & $12 / 17 / 86$ & 248.97 & 406.26 & 655.23 \\
\hline $299-E 25-10$ & $12 / 17 / 86$ & 250.22 & 404.78 & 655.00 \\
\hline $299-E 25-11$ & $12 / 17 / 86$ & 275.77 & 405.51 & 681.28 \\
\hline 299-E 25-23 & $12 / 17 / 86$ & 271.26 & 408.93 & 680.19 \\
\hline $299-E 25-27$ & $12 / 17 / 86$ & 270.15 & 405.98 & 676.13 \\
\hline 299-E26-01 & $12 / 18 / 86$ & 211.19 & 406.06 & 617.25 \\
\hline 299-E26-04 & $12 / 17 / 86$ & 240.01 & 406.14 & 646.15 \\
\hline 299-E27-01 & $12 / 18 / 86$ & 275.30 & 405.75 & 681.05 \\
\hline $299-E 32-01$ & $12 / 18 / 86$ & 250.84 & 405.33 & 656.17 \\
\hline 299-E33-08 & $12 / 18 / 86$ & 245.52 & 405.51 & 651.03 \\
\hline $299-E 33-14$ & $12 / 18 / 86$ & 216.57 & 405.55 & 622.12 \\
\hline 299-E33-17 & $12 / 18 / 86$ & 226.20 & 405.45 & 631.65 \\
\hline $299-E 33-21$ & $12 / 18 / 86$ & 262.90 & 405.50 & 668.40 \\
\hline 299-E34-01 & $12 / 18 / 86$ & 223.87 & 405.55 & 629.42 \\
\hline $699-37-43$ & $12 / 17 / 86$ & 284.33 & 405.84 & 690.17 \\
\hline $699-39-39$ & $12 / 17 / 86$ & 125.29 & 411.36 & 536.65 \\
\hline $699-40-33 A$ & $12 / 17 / 86$ & 107.59 & 410.46 & 518.05 \\
\hline $699-42-40 A$ & $12 / 12 / 86$ & 124.50 & 420.93 & 545.43 \\
\hline $699-42-40 B$ & $12 / 17 / 86$ & 124.65 & 421.81 & 546.46 \\
\hline $699-43-42$ & $12 / 17 / 86$ & 145.24 & 419.24 & 564.48 \\
\hline $699-45-42$ & $12 / 17 / 86$ & 159.23 & 418.10 & 577.33 \\
\hline $699-47-35 A$ & $12 / 17 / 86$ & 64.01 & 412.35 & 476.36 \\
\hline $699-47-35 B$ & $12 / 17 / 86$ & 64.31 & 412.34 & 476.65 \\
\hline $699-47-46$ & $12 / 17 / 86$ & 173.44 & 406.70 & 580.14 \\
\hline
\end{tabular}


TABLE A.l. (contd)

\begin{tabular}{|c|c|c|c|c|}
\hline Wel1 Number & Date & $\begin{array}{l}\text { Depth to } \\
\text { Water (ft) }\end{array}$ & $\begin{array}{c}\text { Elevation } \\
\text { to Water ( } \mathrm{ft} \text { ) } \\
\end{array}$ & $\begin{array}{l}\text { El evation } \\
\text { of Casing } \\
\end{array}$ \\
\hline $699-47-60$ & $12 / 17 / 86$ & 244.92 & 404.92 & 649.84 \\
\hline $699-49-55 A$ & $12 / 17 / 86$ & 124.89 & 405.25 & 530.14 \\
\hline $699-49-57$ & $12 / 17 / 86$ & 147.72 & 405.09 & 552.81 \\
\hline $699-50-42$ & $12 / 17 / 86$ & 55.92 & 410.92 & 466.84 \\
\hline $699-50-53$ & $12 / 17 / 86$ & 151.21 & 405.09 & 556.30 \\
\hline $699-51-63$ & $12 / 17 / 86$ & 164.95 & 406.89 & 571.84 \\
\hline $699-53-35$ & $12 / 17 / 86$ & 134.72 & 396.27 & 530.99 \\
\hline $699-53-47 A$ & $12 / 17 / 86$ & 30.88 & 407.40 & 438.28 \\
\hline $699-53-47 B$ & $12 / 17 / 86$ & 31.14 & 407.44 & 438.58 \\
\hline $699-53-48 A$ & $01 / 15 / 87$ & 36.45 & 406.00 & 442.45 \\
\hline $699-54-34$ & $12 / 17 / 86$ & 142.74 & 407.50 & 550.24 \\
\hline $699-54-45 A$ & $01 / 14 / 87$ & 96.89 & 397.40 & 494.29 \\
\hline $699-54-48$ & $01 / 15 / 87$ & 52.84 & 404.18 & 457.02 \\
\hline $699-55-40$ & $12 / 17 / 86$ & 133.85 & 409.28 & 543.13 \\
\hline $699-55-44$ & $12 / 17 / 86$ & 124.80 & 394.87 & 519.67 \\
\hline $699-55-50 \mathrm{~A}$ & $01 / 15 / 87$ & 38.42 & 404.39 & 442.81 \\
\hline $699-55-50 C$ & $12 / 17 / 86$ & 40.09 & 404.34 & 444.43 \\
\hline $699-55-50 C$ & $01 / 15 / 87$ & 40.25 & 404.18 & 444.43 \\
\hline $699-55-500$ & $12 / 17 / 86$ & 36.10 & 404.34 & 440.44 \\
\hline $699-55-500$ & $01 / 15 / 87$ & 36.25 & 404.19 & 440.44 \\
\hline $699-55-57$ & $12 / 17 / 86$ & 162.27 & 404.39 & 566.66 \\
\hline $699-59-58$ & $12 / 17 / 86$ & 94.23 & 403.54 & 497.77 \\
\hline $699-60-60$ & $12 / 17 / 86$ & 107.93 & 404.10 & 512.03 \\
\hline
\end{tabular}


TABLE A.2. Hanford Water Level Measurements in the Rattlesnake Ridge Aquifer, December 1986

\begin{tabular}{|c|c|c|c|c|}
\hline Well Number & Date & $\begin{array}{l}\text { Depth to } \\
\text { Water (ft) }\end{array}$ & $\begin{array}{c}\text { Elevation } \\
\text { to Water ( } \mathrm{ft}) \\
\end{array}$ & $\begin{array}{l}\text { Elevation } \\
\text { of Casing }\end{array}$ \\
\hline 299-E 26-08 & $12 / 17 / 86$ & 196.62 & 406.04 & 602.76 \\
\hline $299-E 33-12$ & $12 / 18 / 86$ & 217.18 & 405.82 & 623.00 \\
\hline $699-22-70 P$ & $12 / 18 / 86$ & 184.68 & 430.28 & 614.96 \\
\hline $699-42-40 \mathrm{C}$ & $12 / 17 / 86$ & 131.25 & 414.91 & 546.16 \\
\hline $699-46-32$ & $12 / 17 / 86$ & 62.09 & 408.11 & 470.20 \\
\hline $699-47-50$ & $12 / 17 / 86$ & 176.22 & 407.65 & 583.87 \\
\hline $699-49-32 B$ & $12 / 17 / 86$ & 106.19 & 409.36 & 515.55 \\
\hline $699-49-55 B$ & $12 / 17 / 86$ & 125.08 & 405.25 & 530.33 \\
\hline $699-50-45$ & $12 / 17 / 86$ & 42.09 & 409.32 & 451.41 \\
\hline $599-50-48$ & $12 / 17 / 86$ & 142.38 & 408.01 & 550.39 \\
\hline $699-51-46$ & $12 / 17 / 86$ & 36.15 & 408.48 & 444.63 \\
\hline $699-52-46 A$ & $12 / 17 / 86$ & 46.35 & 409.26 & 455.61 \\
\hline $699-52-46 A$ & $01 / 15 / 87$ & 46.49 & 409.12 & 455.61 \\
\hline $699-52-48$ & $12 / 17 / 86$ & 58.89 & 407.13 & 466.02 \\
\hline $699-53-50$ & $12 / 17 / 86$ & 37.86 & 406.35 & 444.21 \\
\hline $699-54-45 B$ & $12 / 17 / 86$ & 33.09 & 459.85 & 492.94 \\
\hline $699-54-45 B$ & $01 / 14 / 87$ & 33.16 & 459.78 & 492.94 \\
\hline $699-54-57$ & $12 / 17 / 86$ & 170.99 & 404.59 & 575.58 \\
\hline $699-56-63$ & $12 / 17 / 86$ & 29.61 & 404.73 & 434.34 \\
\hline
\end{tabular}




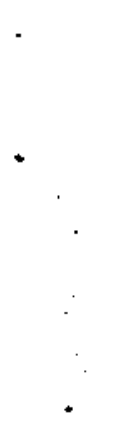




\section{DISTRIBUTION}

No. of

Copies

OFFSITE

2 DOE Technical Information Center

ONSITE

6 DOE Richland Operations Office

M. Anthony

P. J. Krupin

R. J. Navarez

M. W. Shupe

J. J. Sutey

M. W. Tiernan

5 Westinghouse Hanford Company

M. R. Adams

K. A. Gasper

A. G. Law

S. Schaus

BWIP Library
No. of

Copies

32 Pacific Northwest Laboratory

C. S. Cline

D. W. Dragnich

S. Dudziak

R. M. Fruland

M. D. Freshley

M. J. Graham

J. M. Hales

M. S. Hanson

$P$. C. Hays

E. J. Jensen (5)

G. V. Last

T. L. Liikala

V. L. McGhan

P. J. Mitchell

R. W. Nelson

J. R. Raymond

R. Schalla

R. L. Skaggs

R. M. Smith

J. A. Stott lemyre

R. E. Wildung

Publishing Coordination (2)

Technical Report Files (5) 
$\checkmark$ 